\title{
LOCAL-WISDOM-BASED SPA TOURISM IN UBUD VILLAGE OF BALI, INDONESIA
}

\author{
Pradana Gede Yoga Kharisma*, Parwati Komang Shanty Muni \\ International Bali Institute of Tourism, Indonesia \\ *E-mail: yoga@stpbi.ac.id
}

\begin{abstract}
The purpose of this research is to be able to understand the existence of Spa tourism based on local wisdom in Ubud Village, Bali. This research is conducted because there is an inequality between assumption and reality in the field. Generally, Spa tourism using water medium modernly was done by a therapist in a special place for Spa. But, in Ubud, Spa tourism based on local wisdom, which is different from Spa tourism in general, interests tourists. The questions are: why does local-wisdom-based Spa tourism highly interest tourists in Ubud village?; what does the Spa look like?; what are the implications for the society and tourism industry in Ubud? This research was conducted by using qualitative method. Sources and types of research data, both primary and secondary, were obtained in the field through participant observation, interview, and literature study. All data that has been collected was then analyzed critically in the perspective of cultural studies. The results showed that: Local-wisdom-based Spa tourism is very attractive for tourists in Ubud because the price is cheap, but the workmanship and the resulted output are quite good; Localwisdom-based Spa tourism in Ubud Village was conducted in the form of home Spa; a Spa tourism conducted in society's houses by the local community as well as local workmanship and local-wisdom-based products; the development of local-wisdom-based Spa tourism in Ubud has implications for local communities, especially on improving the economy, employment opportunities, empowerment, conservation of local wisdom, emancipation of local communities in tourism, and implications as a new identity for the tourism industry in Ubud.
\end{abstract}

\section{KEY WORDS}

Spa tourism, local wisdom, ubud tourism village, bali tourism.

Bali is a popular cultural tourism destination in the world (Pichard, 2006). The uniqueness of Bali culture attracts many tourists to come again. The high number of tourist visits to Bali encourages the rapid development of tourism industry of this region. Various types of tourist products are now mushrooming in Bali. The growth is not just happening in the tourist areas that have developed before. But, it is also happening to the remote villages with various types of tourism products based on local wisdom of Bali.

The high interest of tourists to tourism products nuanced Balinese culture motivates local government committed to continue developing the area of Bali as a tourist destination based on the concept of "cultural tourism". This means that all industrialization of tourism developed by the community in this area is expected to have Balinese culture nuance. The strategic policy that delivers Bali as a world-renowned cultural destination is worth keeping in place. This is because even though Bali area is developed as a tourist destination of the world, but in reality the local culture of religious nuances are full of cultural values remaining sustainable. Even, many observers claim that the rapid development of Bali's tourism industry causes fertility increase of the growing culture of Bali (Ruastiti, 2010).

Ubud as one of tourist villages in Bali has potential which is adequate as a cultural tourist attraction. In addition to its beautiful natural environment, its friendly community culture is a special attraction for the growing wellness tourism in Ubud village. As one of the tourism objects, Ubud village plays and actively contributes as a host in providing Spa facilities through 97 kinds of business. Since it attracts high demand of tourists, Spa tourism was grown as a tourism mainstay in Ubud village. Based on observations in the field, it seems that the growth of Spa in Ubud Village has exceeded $100 \%$ within the period of 8 
years (Widjaja, 2011). Starting from 2003 until 2011, it has been identified about 410 Spas have been operating and spreading in tourism centers in Bali, including Ubud.

Ubud is famous among the foreign tourists because its location is placed between the rice fields and forest that present the beauty of natural scenery. On the other hand, Ubud is known for its culture, as there are art galleries, arts and dance arenas (Pichard, 2006). The tourists dare to pay expensively to stay in Ubud hotels, villas, and resorts because they want to enjoy the atmosphere of rural calmness in Bali while enjoying the taste of Balinese arts from hundreds of studios in remote villages.

Over the last 10 years, Ubud Village has developed wellness tourism based on local wisdom of Bali. Wellness tourism is a kind of health tourism (Jafari, 2000; Bookman, 2007; Reisman, 2010). The emergence of wellness tourism in Bali seems inseparable from these many areas which have a kind of traditional medicine, supported by the skills of the community in concocting and doing traditional healthcare. Bali natural beauty increasingly adds to the development of this type of tourism potential as a leading tourist in Ubud village. The number of tourists interest in the wellness tourism, particularly Spa, has impacted on the rise of Ubud resorts, such as hotels, inns, beauty clinics, and resorts to develop localwisdom-based Spa (Raiutama, 2011; Smith, 2009; Smith, 2014; Voigt et al, 2014). Spa as wellness tourism is a fitness center that tourists can use to recover their stamina from fatigue during their tour (Smith et al., 2014). In Spa site, the tourists can take care of health as well as relaxation (McKindsey, 2002; Dacanay et al., 2005).

Spa Tourism is considered as one of the most popular tourism attractions for tourists (Chen and Prebensen, 2009; Dun, 1973; Ardel, 1986). Spa as one of tourism types concerning on consumers fitness care, so it becomes a favorite choice for international tourists. In principle, Spa attempts to pamper tourists through treatment by using water medium. The development of a local-wisdom-based Spa in Ubud has created many opportunities for local people (Peris et al, 2015). This means that the development of Spa tourism products that require a lot of local therapists can open employment opportunities for local communities. Not only for tourism school graduates, but also it opens job opportunities for homebound people, housewives, who have traditional massage skills. Moreover, the regularity of the hospitality business environment and the reliability of Bali's infrastructure are increasingly supporting the development of Bali's tourism industry (Widjaja, 2011; UNWTO, 2015; UNECLAC, 2010).

It is interesting to note because so many tourists who come to visit the village of Ubud are not only willing to enjoy the natural scenery and cultural traditions of a unique community, but also because they want to enjoy the unique local-wisdom-based Spa in which they rarely meet elsewhere. In general, Spa tourism using water medium is done in modern way with sophisticated technology. But now, in Ubud Village, a different Spa tourism is developed. The questions are: how is the form of Spa tourism based on local wisdom in Ubud village?, and how are the implications for the community and the development of tourism industry in Ubud Village?

\section{METHODS OF RESEARCH}

The research method used to study the phenomenon of Spa based on local wisdom in Ubud village is qualitative research method. The sources and types of research data, both primary and secondary, were obtained directly in the field through participant observation, interview, and literature study. Primary data were collected using participant observation techniques and interviews (Ten Have, 2004; Travers, 2004). Besides, secondary data were collected by using literature study technique (Hammond and Wellington, 2013). The related informants were selected based on purposive sampling technique. Selected informants include community figures, tourism figures, village elders, and local communities. The addition of informants to complete the data that is considered less done by using snowball sampling technique. As it has been said that this study also uses secondary data obtained from literature studies through the search of similar research results that have been produced by previous researchers. After all data was collected, then the data were analyzed 
critically in the perspective of cultural studies. The results of the study showed, such as, as follows.

\section{RESULTS AND DISCUSSION}

Local-Wisdom-Based Spa Tourism in Ubud Village, Bali. Based on the results of research, it shows that Spa tourism based on local wisdom is very attractive to tourists in Ubud village because the price is cheap but the output is quite good. Although traditionally done, it is based on local wisdom done by ordinary housewives with their own processed products and techniques, but tourists who have enjoyed the local-wisdom-based Spa are satisfied. The nuance of typical house of Ubud village and the freshness of the body that they felt after the massage make many tourists like the type of tourism products.

The free market gives everyone space to compete freely in achieving economic benefits. The number of similar products sold in the market creates intense competition. Not only in price, but a competition is also there in product quality. The phenomenon creates every producer competing to offer good quality with a relatively inexpensive price. Such conditions certainly create a tight competition climate both in terms of quality and price offered. Competition will become more with the support of technology. This is because consumers will become easier to access the desired product information. It is also same as the competition of Spa tourism products in Ubud. The number of tourists who are interested in using Spa services encourage the emergence of local-wisdom-based Spa tourism products which is known as home Spa. Home Spa products offered are relatively low prices compared to Spa tourism that are offered by hotels and villas in Ubud make a lot of tourists turned and dropped their choice on Spa products based on local wisdom that is done by the local community in the homes of local residents.

The number of tourists interested in Spa products is considered as an opportunity by the community in Ubud to participate in offering Spa tourism products. By using their skills and culture, they seized the market. Tourists who mostly stay in the village of Ubud and have enjoyed a good and refreshing home Spa message make tourists use the product repeatedly.

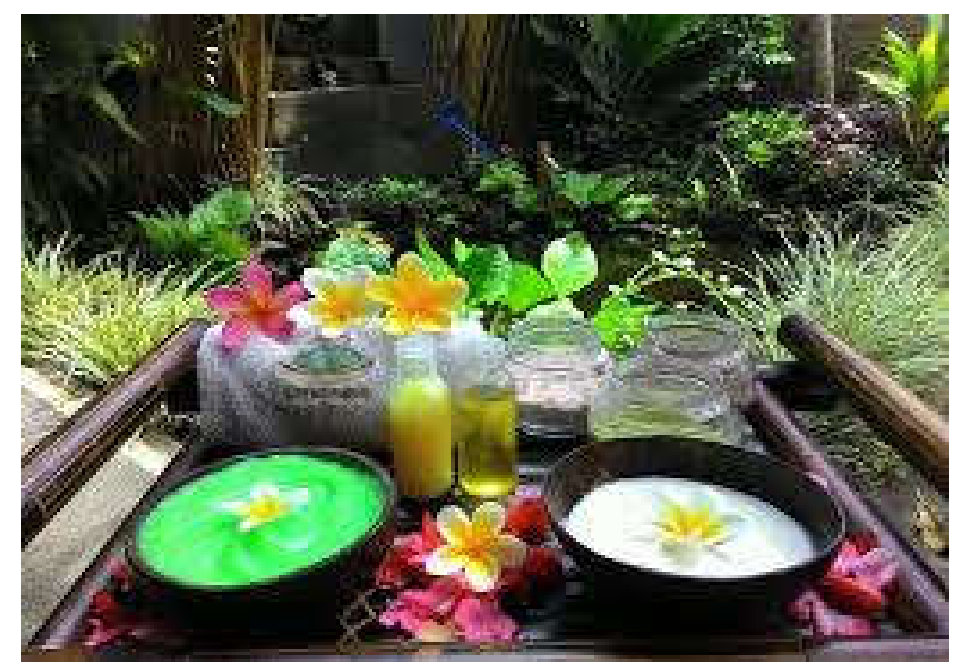

Figure 1 - Coconut Oil and boreh for Spa treatment Source: Courtesy of Yoga, 2017.

The natural potency of Ubud Village that has been beautifully accompanied by the skill of its community in concocting boreh (traditional mask), and massaging is an important factor in building the image and identity of home Spa products offered. With local wisdom, local people are able to gain an economic contribution to tourism development in Ubud. The tourists who are interested in home Spa makes housewives in the village is now beginning to 
glance at the opportunity as a way to seek fortune. Now, besides renting their houses as an accommodation for tourists, local people also provide home Spa services for tourists in Ubud. Below is one of the local-wisdom-based Spa done by the community in Ubud.



Figure 2 - Home Spa in Ubud Village

Source: Courtesy of Yoga, 2017.

Spa tourism based on local wisdom in the village of Ubud is done in form of home Spa. It can be seen from the products used, the way it is worked, the therapists who do it, the place, or the workmanship. Spa tourism based on local wisdom now attracts a lot of tourists in the village of Ubud. The number of tourists interested in the local-wisdom-based Spa tourism is responded positively by local community. It can be seen from the spread of Spa along the highway of Ubud village. Each Spa offers its own uniqueness. The rise of localwisdom-based Spa tourism in the village of Ubud would not be separated from the creativity of local communities in developing these tourism products. Ubud village as a tourist destination that has the beauty of panorama, natural scenery, accompanied by the amount of local community support in developing tourism into a potential capital in developing the village of Ubud as the world's cultural tourism industry. Below is one of the local-wisdombased Spa done by the community in Ubud.

The uniqueness of local-wisdom-based Spa tourism of Ubud village that is familiar seems to be the main attraction for tourists. The integration of various cultural elements of Ubud Village on a local-wisdom-based Spa in Ubud indirectly seems to open and expand employment opportunities for the community, housewives from the area. Since the high number of tourists is interested in the traditional Spa, now housewives who have low education get job opportunities as well as economic contribution to the development of tourism in the region.

Ubud Tourism Village which is now famous for home Spa; a typical Spa that is done traditionally in the house of residents, in addition to having its own interest in terms of workmanship, but also it has a special advantage in terms of production costs of the Spa tourism. It is caused by the simple workmanship that is his own house, the products used such as scrubbing, masks, massage to aroma therapy used is local production processed by local communities traditionally. But although traditional ingredients in the form of lotions with fine granules are smeared throughout the body when bathing, the Spa has feature to smooth blood circulation, and can remove toxins from the body, so that local-wisdom-based Spa is very attractive to tourists. Although home Spa is cheap, but the stiffness and fatigue of tourists are reduced especially if the body is masked by using traditional herbals in the form of powders made in accordance with the skin condition of tourists.

According to Mrs. Nyoman Kondri, one of the traditional Spa therapists, tourists are very happy with the way she massages. By pressing at certain points using her own aromatherapy oil, the tourists feel satisfied, even then often giving her tip, in the form of extra 
money to Mrs. Nyoman. Local-wisdom-based Spa treatment that now seems to be mushrooming in Ubud is dominantly done by local people using traditional products, with traditional craftsmanship techniques, all of which are based on the local wisdom of Ubud Village.

Local wisdom is part of the culture (Zaimah, 2007). Local wisdom can be defined as human intelligence possessed by certain ethnic groups through community experience (Appadurai, 1996). Meaning that local wisdom is the result of certain communities and not necessarily experienced by other communities. The value system inherent in the community is understood as a common property. Every truth value is defined as the common property of the community. The similarity of the truth value comprehension is gained through the long passage of time, throughout the existence of that society.

Local wisdom can be conceptualized as local intelligence (local genius) reflected from knowledge and local policy (local wisdom) (Wahono, 2005). Therefore, local wisdom can be interpreted as a thought about life. The mastery of local wisdom will shape the character of the community concerned on having a noble personality and wise in life. Hence, the development of local-wisdom-based Spa tourism which is done by local people using local cultural skills can be done synergistically in the field of tourism.

The important purpose of wellness tourism not only reaches the satisfaction of tourists on every visit to the tourist attractions, but also it makes their body fit again (Raiutama, 2011). Based on that orientation, there is a correlation between attitude and knowledge of the utilization of tourism facilities where knowledge of Ubud Village people influences the decision of tourists in making a tour to the village of Ubud. Many tourist visits to the village of Ubud aim to enjoy the natural scenery and the uniqueness of local culture. It is like a tit for tat because local people indeed expect tourists to visit their village, so that they can participate and get contribution from the development of tourism in their area. By developing localwisdom-based Spa tourism, they feel that not only earn economic contributions, but also can preserve their cultural traditions. The community's struggle in Ubud village seems able to make Bali as the best Spa destination in the world which is ever declared by one of Germany magazines namely SENSES at the Wellness Award in 2009 (Interview with Putu Sadia, January 2017). Based on the statement, it can be understood that the village of Ubud is not only known as a cultural destination, but also it is known as local-wisdom-based Spa tourist destination of Bali.

As the favorite choice of tourists, local-wisdom-based Spa tourism certainly cannot be separated from the touch of professionals in the field of tourism. The therapists of localwisdom-based Spa, mostly local housewives, are trained. By training, the housewives were able to do the treatment well. They use local spices, oil, and rice as product ingredients. By taking advantage of the opportunity, in practice, it empowers local women in the public sector as a therapist. With the development of local-wisdom-based Spa in the village of Ubud, the unemployed people in the area are reduced. Local-wisdom-based Spa that requires a lot of female workers indirectly impacts on the decline of the number of poverty. Moreover, the arrangement of home Spa interior is styled with elements of local culture seems that it provides economic opportunities significantly for local communities.

The practice of local-wisdom-based Spa in Ubud is very prospective. As stated by the Chairman of the Bali Spa and Wellness Association (BSWA), approximately BSWA members experienced a shortage of 2-3 therapists by 2016 (Denpost, 2016). Though being a therapist is very easy. Skill training done by local people no more than four months to gain about 2 millions salary at a number of Ubud resorts and villas. Ubud as a Tourism Village has contributed in increasing the number of Spa workers. It is noted that the number of Spa in Bali until the year 2016 has reached 1.100 units (Jumarani, 2009). Even if the Spa business competition in Ubud Village is tight; but with the implementation of certain operational standards, the quality of the products can be controlled. Quality products will certainly be able to influence consumer decisions to buy the product. This means that satisfactory service to consumers plays an important role in sustainability of product sales offered. However, in a number of resorts and villas that develop the concept of local-wisdom-based Spa by applying certain SOPs resulted in many therapists objecting and choosing to resign as workers. This 
has resulted in many resort and villa entrepreneurs developing Spa in Ubud frustrated by a shortage of therapists.

Based on observations in the field, it seems that lately the interest of tourists in Ubud to health tourism is very huge. The high interest of tourists in a product can be seen from the speed of product growth in the field (Maslow and Herzeberg, 1954; Pine and Gilmore, 1999). As Spa tour packages that seem to be a priority of tourists who visit Ubud, Ubud as one of the Cultural Tourism Villages is visited by many tourists because they want to enjoy a quality Spa. Spa tourism is made as the top choice because Spa in Ubud is known for its uniqueness and quality. As a cultural tourist destination when tourists come to visit Ubud, they feel like they were in their own houses. A homey and peaceful village atmosphere as well as hospitality attitude of the people encourages tourists to always want to come back to Ubud.

Local-wisdom-based Spa tourism developed by villas and hotels in Ubud is now much designed with the concept of open space. The design of Spa open spaces adopting the base of local wisdom not only has open rooms, but also it uses natural components. Natural environment such as rivers, green rice fields, and steep cliffs are widely used by villas and hotels in Ubud as a Spa. Local-wisdom-based Spa tourism often called 'home Spa' indeed adopts a home atmosphere. In addition to the interior design of the Spa on the products and equipment used, it also uses home appliances. It certainly has plus and minus. In one side, it indeed gives unique and artistic touch, but on the other side, the open space will be easier to be dusty and dirty. It certainly requires extra attention in maintaining the cleanliness of Spa spots. If cleanliness is not paid attention, then it will influence the hygiene treatment. The treatment results cannot be maximal. In service products like Spa, customer service is the most vital component in maintaining the sustainability of consumer interest. Good and bad servicing actors to consumers is the key success of a service business (Upshaw, 1995; Diaz, 2010; Lavado, 2011; Palmer, 2001).

Besides service, promotion of a service business is also important in maintaining the sustainability of these products. As the local-wisdom-based Spa in the village of Ubud which still uses a lot of promotions that are managed by the travel agent, quality of service must be concerned too so that tourists who have felt the good treatment of Spa, they will come back to the place. This means that local-wisdom-based Spa tourism in the village of Ubud is still less to do business promotion. Therefore, visitors of the Spa are very dependent on the tourists visit who already know and love Ubud and have enjoyed the treatment at the Spa.

Implication of Local-Wisdom-Based Spa Tourism for Local Community in Ubud. The development of local-wisdom-based Spa tourism in the village of Ubud indirectly implies on the preservation of traditional medicinal materials management way for treatment and traditional medicine through massage. The practice of local-wisdom-based Spa is very environmentally friendly. It can be seen from the components or products used, the place or location, and the equipment used in the Spa product. Local-wisdom-based Spa tourism uses a lot of natural media. This means that local-wisdom-based Spa treatment dominantly uses elements of local culture both in terms of products and ways to work.

Spa can be defined as hydrotherapy (Crebbin et al, 2005; O'brien, 2006). Through Spa services, it can make consumers feel relaxed, refresh mind, and make body fit again. Spa involves a series of therapeutic massage treatments, body scrubs, bleach masks, milk baths along with music therapy, aromatherapy, and warm drinks of ginger or hot tea (O'brien, 2006). In addition to a massage, in the Spa package, it sometimes also adds the treatment with hair Spa (creambath plus), pedicure-manicure, facial, and others (Crebbin et al, 2005). Spa therapy is widely chosen by consumers because it can be used to reduce headaches, aches, fatigue, anxiety, and so on (Herron, 2008). The added benefit of Spa treatments is feeling calm, comfortable, the skin becomes smoother, firmer, cleaner and muscles are more relaxed. Because of the high demand of women, Spa treatments are generally known as a place of beauty treatments, body care, fitness, health and comfort. Due to the contribution of treatment in the Spa, Spa tourism is identical with women. However, the fact in the field shows that the consumers of Spa tourism products actually are also men. 
The environment setting of Spa location which is made beautiful and easy to reach becomes the main concern for the development of Spa products based on local wisdom. The community makes the modern Spa become a unique and thick nuanced tourist products with the content of local culture. The increase of people's income through their participation in providing Spa's massage products and services encourages many local people to participate in such tourism activities. A tourism product that consumers demand will have implications for the economic improvement agents (Nordin, 2003; Al Jassmi, 2013). The development of a local-wisdom-based Spa in the village of Ubud opens job opportunities and triggers the creativity of local people to continue innovating in the field of Spa. Their growing creativity in the treatment and processing of Spa products increases their income. The access of local people in the tourism industry in Ubud becomes more real. The rotation of the economy over the development of Spa tourism products in Ubud is also increasing along with the increase of creative economic ethos in society.

The development of local-wisdom-based Spa tourism in Ubud Village indirectly has implications on strengthening and empowering local communities. Community participation in Spa tourism products seems to have provided a conducive atmosphere for community mobilizers to pay attention and care of Spa touris, areas. Their availability to cooperate actively and cooperatively has been able to build a sustainable tourism (Eagles, et al, 2002). At the same time, they manifest the situation by developing participation and empowerment of local communities through the Spa practice monitoring group in Ubud.

The development of local-wisdom-based Spa tourism in Ubud village indirectly implies on reducing the risk of crime and increasing emancipation of women in the public sector. Reducing the risk of criminality through productive activities in the field of Spa seems able to reduce the stereotype of local residents as well as minimize the inequality distance between groups that can lead to social jealousy as a potential crime. Although women in Ubud participate in public sector work as a Spa product workers, but they still do their traditional duties as housewives.

On the other hand, the development of local-wisdom-based Spa tourism in the village of Ubud indirectly has implications in maintaining the beauty of natural environment. It is because the therapists, that mostly the local community, use products and treatments that are environmentally friendly and still maintain the cleanliness of the environment. The need for extensive land for Spa location gets the local community's attention. Because they jointly carry out the practice of Spa, then they also face and conduct the preparation of the necessary natural location together. The beauty of Ubud Village is one of local-wisdombased Spa tourism's attractions. The more positive the assessment of tourists on the products offered, the more positive the tourists will choose the products back. It indirectly can maintain the function and sustainability of the local natural environment. Local people also enjoy living in the beautiful environment.

Besides, the development of local-wisdom-based Spa tourism in the village of Ubud indirectly influences the beauty of local wisdom in Ubud village. Local wisdom used as Spa products such as oil and rice for traditional boreh healing through treatment. In addition, the activities of Spa tourism conducted by the community in Ubud village indirectly have implications on opening the active local cultural involvement in legalizing the product and Spa treatment in Ubud Tourism Village. The institutioning process of local-wisdom-based Spa treatment indirectly seems to participate in maintaining ethics and morals of local communities, as treatment agents who can slightly reduce the tasks in terms of custom in order to maintain the good name of Ubud Tourism Village culturally.

\section{CONCLUSION AND SUGGESTIONS}

Based on the above explanation, it can be concluded that the results of research show that local-wisdom-based Spa tourism is very attractive to tourists in Ubud because the price is cheap, the workmanship is good, the atmosphere is more homey, and the body is more refreshed. Local-wisdom-based Spa tourism in Ubud Village is done in the form of home Spa. It can be seen from the place and the atmosphere of workmanship, the products used, 
the way it is worked, and the therapists who do it. The development of local-wisdom-based Spa tourism in Ubud village has implications for improving the economy, employment opportunities, empowerment, emancipation of local people, the preservation of local wisdom, and a new identity for tourism in Ubud.

The development of local-wisdom-based Spa tourism known as the home Spa in Ubud affects the development of tourism industry in Ubud. The contribution of the development of home Spa seems to add an icon for the village of Ubud as a tourist area of Spa because it has many good Spa services. Nowadays, Ubud is not only known as a cultural tourism destination, but also known as a Spa tourism destination.

Moreover, the development of Spa tourism has implications for improving the living standards, the economy, and the welfare of local communities. Success in offering Spa tourism based on local wisdom has been able to attract local people, especially housewives in focusing the profession as a housewive Spa therapist. It certainly means economic, as empowerment, and emancipation for the local community. The development of local-wisdombased Spa tourism has implications for the preservation of local wisdom. It can be seen from the utilization of boreh/spices mask, coconut oil, local rice, as Spa treatment ingredients, and so forth. In addition to the implications for the preservation of local culture, the development of home Spa also gives implications on the natural environment of Ubud village, the beauty of the natural environment, and the cleanliness of the surrounding natural environment. Besides, the development of local-wisdom-based Spa in Ubud Village has implications for economic improvement, job opportunities, empowerment, community emancipation, and the preservation of local wisdom.

As a suggestion, in order that the Spa tourism product can be developed continuously, it is necessary to cooperate with related parties, starting from community figures, traditional figures, security, government, community groups, and related experts (economists, Spa experts, tourism experts). In order to keep the quality maintained, regular training needs to be done so that the regeneration process can take place. Cooperation between all parties that are mutually beneficial is the basic capital that will be able to realize sustainable community-based tourism.

\section{REFERENCES}

1. Al Jassmi, L. (2013). Gulf Countries Cooperation Health Travel Market Experience and Opportunities International. Monaco: Medical Travel Exhibition and Conference.

2. Appadurai, A. (1996). Modernity at Large Cultural Dimensions of Globalization. London: University Of Minnesota Press.

3. Ardel, D.B. (1986). High Level Wellness: An Alternative to Doctors, Drugs and Disease. Berkeley CA: Ten Speed Press.

4. Bookman, M \& Bookman, K. (2007). Medical Tourism in Developing Countries. New York: Palgrave macmilian.

5. Chen, J.S. \& Prebensen, N. (2009). Wellness as Tourist Motivation. Case of Taiwan. In: Bushell, R. \& Sheldon, P.J. (Eds.) Wellness and tourism. Mind, Body, Spirit, Place (pp.231-238). New York: Cogniznat Communication.

6. Crebbin-Bailey, J., Harcup, J. W., Harrington, J., \& Habia. (2005). The Spa book: the official guide to Spa therapy. London: Thomson.

7. Dacanay, J. \& Rodolfo, M. (2005). Challenges in Health Service Trade: Phillippine Case. Disccussion Paper No. 2005-30. Makati: Phillipine Institute for Development Studies.

8. Denpost. (2016). Minat Warga Bali Bekerja ke Luar Negeri Tinggi. http://denpostnews.com/2016/10/22/minat-warga-bali-bekerja-ke-luar-negeri-tinggi/

9. Diaz, F. (2010). Tourism and Hospitality Development and Management: Competitive Strategies and Policies for Tourism Destinations: Quality, Innovation and Promotion. New York: Nova Sciences Publisher.

10. Dunn, L. (1973). High Level Wellness. Arlington: Beatty.

11. Eagles, P.F.J., McCool, S.F., \& Haynes, C.D.A. (2002). Sustainable Tourism In Protected Areas: Guidelines For Planning and Management. Cambridge: IUCN. 
12. Hammond, M. \& Wellington, J. (2013). Research Methods: The Key Concepts. Abingdon: Routledge.

13. Herron, T. (2008). The Spa \& Body Therapist: 5 Keys to Energy, Balance and Bliss. Ropley: O Books.

14. Jafari, J. (2000). Encyclopedia of Tourism. London: Routledge.

15. Jumarani, L. (2009). The Essence of Indonesian Spa: Spa Gaya Jawa dan Bali. Jakarta: Gramedia Pustaka.

16. Lavado, R. (2011). Profile of Private Hospitals in the Phillippines. Disscusion Paper No. 2011-Makati: Phillippine Institute for Development Studies.

17. Maslow, A. \& Herzeberg, A. (1954). Hierarcy of Needs: Motivation and Personality. New York: Harper.

18. Nordin, S. (2003). Tourism Clustering \& Innovation: Path to Economic Growth and Development. Sweden: Europan Tourism Research Institute.

19. O'Brien, K. (2006). Spa Style Asia-Pacific: Therapies, Cuisines, Spa. London: Thames \& Hudson.

20. Palmer, A. (2001). Principles of Services Marketing (3rd). London: McGraw-Lill.

21. Peris-Ortiz, M. \& Alvarez-Garcia, J. (2015). Health and Wellness Tourism: Emergence Of New Market Segment. Switzerland: Springer International Publishing Switzerland.

22. Pichard, M. (2006). Bali, Pariwisata Budaya dan Budaya Pariwisata. Jakarta: Gramedia.

23. Pine, B. J. \& Gilmore, J.H. (1999). The Experience Economy. Work Is Theatre \& Every Business a Stage. Boston: Harvard Business School Press.

24. Raiutama. (2011). Dimensions of Tourism Economics: Study on The Economic Impact and The Comparative Advantage of Tourism in Bali's Regencies and Cities. Denpasar: Dhayana Pura.

25. Reisman, D. (2010). Health Tourism: Social Welfare through International Trade. London: E.Elgar.

26. Ruastiti, N. M. (2010). Seni Pertunjukan Pariwisata Bali. Yogyakarta: Kanisius.

27. Smith, M. \& Puczko, L. (2009). Health and Wellness Tourism. London: ButterworthHeinemann.

28. Smith, M. \& Puczko, L. (2014). Health, Tourism and Hospitality: Spas, Wellness and Medical Travel (2nd Ed.). London: Routledge.

29. Ten Have, P. (2004). Understanding Qualitative Research and Ethnomethodology. London: SAGE Publications.

30. Travers, M. (2004). Qualitative Research through Case Studies. London: SAGE Publications.

31. United Nations Economic Commission for Latin America and the Carrebian. (2010). Medical Tourism: a Survey. Washington: UNECLAC.

32. Upshaw, L. (1995). Building Brand Identity: A Strategy for Success in Hospitality Marketplace. New York: John Wiley and Sons.

33. Voigt, C. \& Pforrs, C. (2014). Wellness Tourism: A Destination Perspective. New York: Routledge.

34. Wahono, F. (2005). Pangan, Kearifan Lokal dan Keanekaragaman Hayati. Yogyakarta: Penerbit Cindelaras Pustaka Rakyat Cerdas.

35. Widjaja. (2011). Otonomi Daerah dan Daerah Otonom. Jakarta: PT Raja Grafindo Persada.

36. World Tourism Organization (UNWTO). (2015). Collection of Tourism Expenditure Statistics. Madrid: World Tourism Organization.

37. Zaimah. (2007). Kearifan Masyarakat Kampung Kuta Bagi Kelestarian Sumberdaya Alam dan Lingkungan (Studi Kasus: Desa Karangpaninggal, Kecamatan Tambak Sari, Kabupaten Ciamis, Jawa Barat) (Tesis Lingkungan). Jakarta: UI (Tidak diterbitkan). 